\title{
Catalogue of the type-specimens of Bolitophilidae, Diadocidiidae and Ditomyiidae (Diptera, Bibionomorpha) in the Natural History Museum, London
}

\author{
Rafaela Lopes Falaschi ${ }^{1} \&$ Dalton de Souza Amorim ${ }^{1,2}$
}

\begin{abstract}
${ }^{1}$ Faculdade de Filosofia, Ciências e Letras de Ribeirão Preto, Universidade de São Paulo. Av. Bandeirantes 3900, 14040-901 Ribeirão Preto-SP. Brazil. rlfalaschi@gmail.com

22dsamorim@usp.br
\end{abstract}

\begin{abstract}
Catalogue of the type-specimens of Bolitophilidae, Diadocidiidae and Ditomyiidae (Diptera, Bibionomorpha) in the Natural History Museum, London. A commented list of the types of three families of Bibionomorpha - Bolitophilidae, Diadocidiidae and Ditomyiidae - housed at the Natural History Museum (London) is provided. This includes four holotypes and one paratype of five species of Bolitophilidae; one paratype and three syntypes of two species of Diadocidiidae; and 17 holotypes, 91 paratypes, four lectotypes, and fourteen paralectotypes of 38 species of Ditomyiidae. Lectotypes are designated for the Neotropical species of the ditomyiids Australosymmerus (Melosymmerus) bisetosus Edwards, 1940 and A. (M.) pediferus Edwards, 1940.
\end{abstract}

KEYWORDS. Nomenclature; scientific collections; taxonomy; types.

The Natural History Museum of London (formerly, British Museum of Natural History) is one of the most important research institutions holding scientific collections of organisms in the world, in terms of number of specimens, number of types, and geographic amplitude. A number of dipterists have worked there since its foundation in 1881. In the context of the families covered in this paper, it is worth referring to Frederick Wallace Edwards (1888-1940) and Paul Freeman (1916-2010) for their contributions to the systematics of different groups of Bibionomorpha, as well as of other families of Diptera.

Bolitophilidae and Ditomyiidae are small families of Mycetophiliformia (sensu Hennig 1954). The distribution of bolitophilids is mainly Holarctic, except for three species known from Taiwan (Ševčík \& Papp 2004; Bechev \& Chandler 2011). Only one extant genus is recognized, Bolitophila Meigen, 1818, with 64 described species (Bechev \& Chandler 2011), currently divided in two subgenera: Bolitophila s.str. and Cliopisa Enderlein, 1936.

The Diadocidiidae also corresponds to a small family of Mycetophiliformia, in the suborder Bibionomorpha, with 24 extant species in two genera, including the recent genus Diadocidia and a fossil genus from the Cretaceous amber from Katchin (Myamar) with one species, Docidiadia burmitica (Blagoderov \& Grimaldi 2004). The genera Diadocidia is divided in three subgenera: Adidocidia Laštovka \& Matile, 1972, Diadocidia Ruthe, 1831 and Taidocidia Papp \& Ševčík, 2005 (Blagoderov 2007; Bechev \& Chandler 2011). The recent species of the family are found in the Holarctic, Oriental, Australasian/Oceanian, and Neotropical regions.

The fungus gnats family Ditomyiidae is more speciose, represented by 15 extant genera and more than 100 described species, with fossil records dating back to the Eocene of Australia (Evenhuis 1994). The Ditomyiidae, along with Bolitophilidae, Diadocidiidae and Keroplatidae, comprise the Keroplatoidea (Hippa \& Vilkamaa 2005), further recognized as a well-supported clade within the Mycetophiliformia by Amorim \& Rindal (2007).

Little is known about the biology of these families. Bolitophilid larvae are often found in sporophores of fleshy fungi (Rindal et al. 2008), while ditomyiids are associated to bracket fungi (Basidiomycota, Polyporaceae) in rotten wood (Munroe 1974), where they build their galleries. With respect to diadocidiids, a species from Japan had the adult reared from a larva mining the sporophore of a Polyporaceae fungus (Basidiomycota) (Sasakawa 2004).

This paper provides a list of the type-specimens of the families Bolitophilidae, Diadocidiidae, and Ditomyiidae in the collection of the Natural History Museum (London, England), following a recommendation of the International Code of Zoological Nomenclature (ICZN 1999: 72F.4).

The name combinations and spellings follow the Palearctic catalogues for Bolitophilidae (Plassmann 1988; Bechev \& Chandler 2011), Ditomyiidae (Mamaev \& Krivosheina 1988), and Diadocidiidae (Bechev \& Chandler 2011). We follow Ribeiro et al. (2007) and Yamaguchi \& Lamas (2009) in standardizing catalographic information. For each species section, the first line provides the name and authorship. The next lines provide the taxon's original name (including figure citations), relevant references citing the species, type locality, as well as information regarding the condition of the type specimens, including a list of parts missing, if that applies. Label data are quoted in double quotation marks. In case of handwriting on printed labels, the handwritten text is 
reproduced in italics; completely handwritten and printed labels are reproduced in regular font. For the sake of clarity, additions to some of the original information of labels, such as abbreviated collecting dates and incomplete locality and names of collectors, are included within square brackets.

\section{Bolitophilidae}

\section{Bolitophila (Bolitophila) spinigera Edwards, 1925}

Edwards, 1925: 514 (original description); 663, figure 2 (female terminalia). Type locality: United Kingdom [Scotland, Highland, Dingwall].

Holotype male, with labels: (1) printed on red round paper: "Holo- | type"; (2) printed with handwritten inscriptions on red round paper: "Type | O"; (3) handwritten on white paper: "Dingwall, | Cromarty. | 29.V.1911. | Lt.Col.Yerbury. | 1911.442"; (4) printed with handwritten inscriptions on white paper: "HOLOTYPE $\mid$ Bolitophila $\mid$ spinigera $\mid$ Edwards det.J.E.Chainey,1995"; (5) printed on white paper: "BMNH(E) \# | 236639". Condition of the type: pinned exemplar, terminalia in balsam.

\section{Bolitophila (Cliopisa) edwardsiana Stackelberg, 1969}

Stackelberg, 1969: 248 (original description); 248, figure 3 (male terminalia). Type locality: Northwest European Russia [Sankt-Petersburg Region].

Paratype male, with labels: (1) printed on yellow round paper: "PARA- | TYPE"; (2) printed with handwritten inscriptions on white paper: “Толмачево Лужск | Лениград О.26.v. | Штакелъберг938."; (3) printed with handwritten inscriptions on white paper: "Bolitophila.65 edwardsiana, sp. nov. | Stackelberg det."; (4) printed on red paper: "Paratypus"; (5) printed on white paper: "BMNH(E) \#| 253408". Condition of the type: pinned exemplar, terminalia on slide.

\section{Bolitophila (Cliopisa) fumida Edwards, 1941}

Edwards, 1941: 22 (original description); 22 (male terminalia). Type locality: United Kingdom [Inverness, Aviemore]

Holotype male, with labels: (1) printed on red round paper: "HOLOTYPE"; (2) printed on red round paper: "Type"; (3) printed on white paper: "Inverness: | Aviemore. | vi.1931. | F.W.Edwards. | B.M.1931305."; (4) handwritten on red paper: "Type of | Bolitophila | fumida Edws"; (5) printed with handwritten inscriptions on white paper: "HOLOTYPE $\mid$ Bolitophila $\mid$ fumida $\mid$ Edwards | det.J.E.Chainey,1996"; (6) printed on white paper: "BMNH(E) \# | 236637". Condition of the type: pinned exemplar, terminalia in balsam.

\section{Bolitophila (Cliopisa) maculipennis Walker, 1836}

Walker, 1836: 179 (original description). Type locality: United Kingdom. Holotype male, with labels: (1) handwritten on white paper: "W"; (2) printed on blue round paper: "Type"; (3) handwritten on blue round paper: "56 150"; (4) printed on white paper: "maculipennis"; (5) printed on white paper: "HOLOTYPE of | Bolitophila maculipennis | Walker, 1836 | Det. N.P.Wyatt 2002"; (6) printed on white paper: "GREAT BRITAIN"; (7) printed on white paper: "BMNH(E) \# | 236638". Condition of the type: pinned exemplar, antennae distally broken, terminalia in balsam.

\section{Bolitophila (Cliopisa) pseudohybrida Landrock, 1912}

Landrock, 1912: 45 (original description). Type locality: Poland, Strzygi. Holotype male, with labels: (1) printed on red round paper: "HOLOTYPE"; (2) printed on red round paper: "Type"; (3) handwritten on white paper: "HOLOTYPE | Bolitophila | triangulata Edws."; (4) printed with handwritten inscriptions on white paper: "Sheviock, | Cornwall. | 13.IX.1912 | Lt.-Col.Yerbury. | 1912-415."; (5) printed with handwritten inscriptions on white paper: "HOLOTYPE $\mid$ Bolitophila $\mid$ triangulata | Edwards | det.J.E.Chainey,1996"; (6) printed on white paper:
"BMNH(E) \# | 236640". Condition of the type: pinned exemplar, terminalia in balsam.

\section{Diadocidiidae}

Diadocidia (Adidocidia) nigripalpis Edwards, 1940

Edwards, 1940: 443 (original description). Type locality: Brazil, Santa Catarina, [Seara], Nova Teutônia.

Syntype male with labels: (1) printed with handwritten inscriptions on white paper: "10.7.1938 $\mid$ Brasilien $\mid$ Nova Teutonia $\left|27^{\circ} 11^{\prime} \mathrm{B}, 52^{\circ} 23^{\prime} \mathrm{L}\right|$ Fritz Plaumann"; (2) printed on white paper: "Brit. Mus. | 1938-682.”; (3) printed on blue round paper: "SYN- | TYPE"; (4) printed with handwritten inscriptions on white paper: "Diadocidia | nigripalpis Edw. | F.W.Edwards 1939"; (5) printed with handwritten inscriptions on white paper: "SYNTYPE $\mid$ Diadocidia | nigripalpis $\mid$ Edwards | det. J.E. Chainey,1996"; (6) printed on red round paper: "Type"; (7) printed on white paper: "BMNH(E) \# | 253409". Condition of the type: pinned exemplar, very damaged, without antennae, legs, wings and abdomen, terminalia in glycerin.

Syntype male with labels: (1) printed with handwritten inscriptions on white paper: “9.7.1939 | Brasilien | Nova Teutonia $\left|27^{\circ} 11^{\prime} \mathrm{B}, 52^{\circ} 23^{\prime} \mathrm{L}\right|$ Fritz Plaumann"; (2) printed on white paper: "Brit. Mus. | 1939-628."; (3) printed on blue round paper: "SYN- | TYPE"; (4) printed with handwritten inscriptions on white paper: "SYNTYPE| Diadocidia | nigripalpis $\mid$ Edwards | det.J.E.Chainey,1996"; (5) printed on white paper: "BMNH(E) \# | 253410". Condition of the type: pinned exemplar, without right antenna and left wing, terminalia on slide.

Syntype male with the same labels as in the syntype above, with label (1) differing in the first line: "9.6.1939", and label (5) in the second line: "253411". Condition of the type: pinned exemplar, without abdomen, wings in slide.

\section{Diadocidia (Diadocidia) cizeki Ševaík, 2003}

Ševčík, 2003: 64 (original description); 66, figures 4-7 (male terminalia). Type locality: Papua New Guinea [Mandang Province, Halopa Village]. Paratype male, with labels: (1) printed on yellow round paper: "PARA- | TYPE"; (2) printed on white paper: "Papua New Guinea, Mandang prov. | Halopa village, primary rain forest | $600 \mathrm{~m}$ a.s.1. | December 2000 | Lukáš Č́žek leg. (Malaise trap)"; (3) printed on red paper: "Diadocidia cizeki | spec. nov. | Paratypus (male) | des. Jan Ševčík, 2003”; (4) printed on white paper: "J. ŠEVČíK Coll. | BMNH(E)2004-183"; (5) printed on white paper: "BMNH(E) \#950622". Condition of the type: entire exemplar in glycerin.

\section{Ditomyiidae}

\section{Australosymmerus naevius Colless, 1970}

[not formally assigned to any of the subgenera of Australosymmerus; Munroe, 1974: 99].

Colless, 1970: 92 (original description); 87, plate I, figure D (wing); 93, figure 11 (male terminalia, ventral view), figure 12 (male terminalia, lateral view) and figure 13 (gonocoxite). Type locality: [Australia, New South Wales], Kangaroo Valley.

Paratype male, with labels: (1) printed on white paper: "Nowa Nowa, Vic. 28 Oct.1961 | D.H. Colless"; (2) printed on yellow round paper: "PARAIYPE."; (3) printed with handwritten inscriptions on blue paper: "PARATYPE $\mid$ Australosymmerus | naevius Colless"; (4) printed with white paper: "BMNH(E) \# | 253317". Condition of the type: pinned exemplar.

\section{Australosymmerus peruensis Munroe, 1974}

[not formally assigned to any of the subgenera of Australosymmerus; Munroe, 1974: 99]

Munroe, 1974: 64 (original description); 152, figure 34 (male terminalia); 173, figure 65a (wing). Type locality: Peru, Cuzco, Quincemil. 
Paratype male, with labels: (1) printed with handwritten inscriptions on yellow round paper: "Para- | type | B.M.1972-341"; (2) printed on white paper: "Quincemil | Cuzco PERU | 1-15.XI.1962 | L.Pena. 700m.”; (3) printed with handwritten inscriptions on blue paper: "PARATYPE | Australosymmerus |peruensis | Munroe"; (4) printed with white paper: "BMNH(E) \# | 253353". Condition of the type: pinned exemplar, without left wing, terminalia in glycerin.

\section{Australosymmerus trivittatus (Edwards, 1927)}

\section{[Centrocnemis]}

[not formally assigned to any of the subgenera of Australosymmerus; Munroe, 1974: 99]

Edwards, in Tonnoir \& Edwards, 1927: 759 (original description); plate 66 , figure 127-128 (hypopygium). Type locality: New Zealand, Governor's Bay.

Holotype male, with labels: (1) printed on red round paper: "HOLO- |TYPE"; (2) printed on red round paper: "Type"; (3) handwritten on white paper: "Centrocnemis | trivittata Edw."; (4) printed with white paper: "New Zealand: | Governor's Bay. | 20-29.ix.1922. | J.F.Tapley. | B.M. 1923-20"; (5) printed with handwritten inscriptions on white paper: "HOLOTYPE| Centrocnemis | trivittata | Edwards | det.J.E.Chainey, 1995"; (6) printed on white paper: "BMNH(E) \# | 253296". Condition of the type: pinned exemplar, right wing glued on triangle paper, without abdomen.

Paratype male, with labels: (1) printed on yellow round paper: "PARA- | TYPE"; (2) printed on white paper: "New Zealand: | Governor's Bay. | 20-29.ix.1922. | J.F.Tapley. | B.M. 1923-20"; (3) printed with handwritten inscriptions on white paper: "PARATYPE $\mid$ Centrocnemis $\mid$ trivittata | Edwards | det.J.E.Chainey, 1995"; (4) printed on white paper: "BMNH(E) \# | 253297". Condition of the type: pinned exemplar, very damaged, without abdomen, all parts glued on rectangle - both wings, head, undetermined legs, antennae - and triangle - abdomen and thorax - paper, right wing glued on other triangle paper.

Paratype male, with labels: (1) printed on white paper: "New Zealand: | Governor's Bay. |20-29.ix.1922. | J.F.Tapley. | B.M. 1923-20"; (2) printed on yellow round paper: "PARA- | TYPE"; with the same labels (3) and (4) as in the paratype above, with label (4) differing in the second line: "253298". Condition of the type: pinned exemplar, without antennae, terminalia in glycerin.

\section{Australosymmerus (Araeostylus) bivittatus (Freeman, 1951) [Australomyia]}

Freeman, 1951: 9 (original description); plate I, figure 4 (male terminalia, dorsal view). Type locality: [Chile, Llanquihue Province], Casa Pangue.

Holotype male, with labels: (1) printed on white paper: "Casa Pangue. | 410.xii.1926."; (2) printed with handwritten inscriptions on red paper: “Australomyia $\mid$ bivittata $\mid$ Freeman.| HOLOTYPE"; (3) printed on red round paper: "HOLO- |TYPE"; (4) printed on white paper: "S.Chile: | Llanquihue prov. | F. \& M.Edwards. | B.M.1927-63"; (5) printed on white paper: "BMNH(E) \# | 253330". Condition of the type: pinned exemplar, right antenna distally broken.

Paratype female, with labels: (1) printed on yellow round paper: "PARA- | TYPE"; (2) printed on white paper: "Casa Pangue.| 4-10.xii.1926."; (3) printed on white paper: "S.Chile: | Llanquihue prov. |F. \& M.Edwards. | B.M.1927-63"; (4) handwritten on yellow paper: "Australomyia | bivittata | FREEMAN | PARATYPE"; (5) printed on white paper: "BMNH(E) \# | 253331". Condition of the type: pinned exemplar.

Paratype female, with the same labels as in the first paratype, with label (5) differing in the second line: "253332". Condition of the type: pinned exemplar.

Paratype female, with the same labels as in the first paratype, with label (5) differing in the second line: "253333". Condition of the type: pinned exemplar.

Paratype female, with the same labels as in the first paratype, with label (5) differing in the second line: "253334". Condition of the type: pinned exemplar.
Paratype male, with the same labels as in the first paratype, with label (5) differing in the second line: "253336". Condition of the type: pinned exemplar, abdomen glued on rectangle plastic.

Paratype male, with the same labels as in the first paratype, with label (5) differing in the second line: " 253335 ". Condition of the type: pinned exemplar, abdomen glued on rectangle plastic.

Paratype female, with the same labels as in the first paratype, with label (5) differing in the second line: "253339". Condition of the type: pinned exemplar, right wing glued on rectangle plastic.

Paratype male, with labels: (1) printed on yellow round paper: "PARA- | TYPE"; (2) printed on white paper: "Peulla. | 12-13.xii.1926."; (3) printed on white paper: "S.Chile: | Llanquihue prov. |F. \& M.Edwards | B.M.1927-63"; (4) handwritten on yellow paper: "Australomyia bivittata | FREEMAN | PARATYPE"; (5) printed on white paper: "BMNH(E) \# | 253338". Condition of the type: pinned exemplar, without antennae.

Paratype male, with the same labels as in the eighth paratype, with label (5) differing in the second line: "253341". Condition of the type: pinned exemplar, without right antenna and left antenna distally broken.

Paratype female, with the same labels as in the eighth paratype, with label (5) differing in the second line: " 253346 ". Condition of the type: pinned exemplar.

Paratype female, with the same labels as in the eighth paratype, with label (5) differing in the second line: "253344". Condition of the type: pinned exemplar, without antennae.

Paratype male, with the same labels as in the eighth paratype, with label (5) differing in the second line: "253347". Condition of the type: pinned exemplar, without antennae, terminalia in balsam.

Paratype male, with labels: (1) printed on yellow round paper: "PARATYPE"; (2) printed on white paper: "Ancud. | 17-19.xii.1926."; (3) printed on white paper: "S.Chile: | Chiloe I. | F. \& M.Edwards. | B.M.1927-63"; (4) printed with handwritten inscriptions on yellow paper: "Australomyia $\mid$ bivittata | Freeman. | PARATYPE."; (5) printed on white paper: "BMNH(E) \# | 253340". Condition of the type: pinned exemplar.

Paratype female, with labels: (1) printed on yellow round paper: "PARA- | TYPE"; (2) printed on white paper: "Puntra.|19.xii.1926."; (3) printed on white paper: "S.Chile: | Chiloe I. | F. \& M.Edwards. | B.M.1927-63"; (4) printed with handwritten inscriptions on yellow paper: "Australomyia | bivittata | Freeman. | PARATYPE."; (5) printed on white paper: "BMNH(E) \# | 253345". Condition of the type: pinned exemplar.

Paratype male, with the same labels as in the paratype above, with label (4) handwritten on yellow paper and label (5) differing in the second line: " $253348 "$ ". Condition of the type: pinned exemplar, right antenna distally broken.

Paratype male, with labels: (1) printed on yellow round paper: "PARA- | TYPE"; (2) printed on white paper: "Castro. |20-22.xi.1926."; (3) printed on white paper: "S.Chile: | Chiloe I. | F. \& M.Edwards. | B.M.1927-63"; (4) printed with handwritten inscriptions on yellow paper: "Australomyia | bivittata | Freeman. | PARATYPE.”; (5) printed on white paper: "BMNH(E) \# | 253351". Condition of the type: pinned exemplar.

Paratype male, with labels: (1) printed on yellow round paper: "PARATYPE"; (2) handwritten on white paper: "Train to Castro. | 19.XII.1926"; (3) printed on white paper: "S.Chile: | Chiloe I. | F. \& M.Edwards. | B.M.1927-63"; (4) handwritten on yellow paper: "Australomyia bivittata | FREEMAN | PARATYPE"; (5) printed on white paper: "BMNH(E) \# | 253349". Condition of the type: pinned exemplar.

Paratype female, with the same labels as in the paratype above, with label (5) differing in the second line: "253350". Condition of the type: pinned exemplar.

Paratype female, with the same labels as in the seventh paratype, with label (4) printed with handwritten inscriptions on yellow paper: "Australomyia | bivittata | Freeman. | PARATYPE." and label (5) differing in the second line: "253343". Condition of the type: pinned exemplar, right wing glued on rectangle plastic.

Paratype male, with labels: (1) printed on yellow round paper: "PARATYPE"; (2) printed on white paper: "Bariloche | 8.xi-1.xii.1926."; (3) 
printed on white paper: "Argentina: | Terr.Rio Negro. | F. \& M.Edwards. | B.M.1927-63"; (4) handwritten on yellow paper: "Australomyia | bivittata | FREEMAN | PARATYPE"; (5) printed on white paper: "BMNH(E) \# | 253337". Condition of the type: pinned exemplar.

Paratype male, with labels: (1) printed on yellow round paper: "PARATYPE"; (2) printed on white paper: "Nahuel Huapi, | Puerto Blest. | 23.xii.1926."; (3) printed on white paper: "Argentina: | Terr.Rio Negro. | F. \& M.Edwards. | B.M.1927-63"; (4) printed with handwritten inscriptions on yellow paper: "Australomyia| bivittata | Freeman. PARATYPE."; (5) printed on white paper: "BMNH(E) \# | 253342”. Condition of the type: pinned exemplar.

\section{Australosymmerus (Araeostylus) simplex (Freeman, 1951) [Australomyia]}

Freeman, 1951: 8 (original description); plate I, figure 3 (male terminalia, dorsal view). Type locality: Argentina, Rio Negro, Correntoso Lake.

Holotype male, with labels: (1) printed with handwritten inscriptions on red paper: "Australomyia $\mid$ simplex $\mid$ Freeman. |HOLOTYPE.”; (2) printed on red round paper: "HOLO- | TYPE."; (3) printed on white paper: "HOLO- | TYPE"; (4) printed on white paper: "Argentina: | Terr.Rio Negro. | F. \& M.Edwards. | B.M.1927-63”; (5) printed on white paper: "BMNH(E) \# | 253321". Condition of the type: pinned exemplar, terminalia on slide.

Paratype male, with labels: (1) printed on yellow round paper: "PARA- | TYPE"; (2) printed on white paper: "L. Correntoso. | 18-25.xi.1926."; (3) printed on white paper: "Argentina: | Terr.Rio Negro. | F. \& M.Edwards. B.M.1927-63"; (4) handwritten on yellow paper: "Australomyia | simplex | FREEMAN | PARATYPE"; (5) printed on white paper: "BMNH(E) \# 253325 ". Condition of the type: pinned exemplar, right antenna distally broken.

Paratype male, with the same labels as in the first paratype, with label (4) differing in the third line: "Freeman." and label (5) in the second line: "253324". Condition of the type: pinned exemplar, without antennae.

Paratype male, with the same labels as in the first paratype, with label (4) differing in the third line: "Freeman." and label (5) in the second line: " 253323 ". Condition of the type: pinned exemplar, without head and left wing.

Paratype male, with labels: (1) printed on yellow round paper: "PARATYPE"; (2) printed on white paper: "Nahuel Huapi, | Puerto Blest. | 23.xii.1926.”; (3) printed on white paper: "Argentina: | Terr.Rio Negro. |F. \& M.Edwards. | B.M.1927-63"; (4) handwritten on yellow paper: "Australomyia | simplex | Freeman. | PARATYPE."; (5) printed on white paper: "BMNH(E) \# | 253326". Condition of the type: pinned exemplar.

Paratype male, with the same labels as in the fifth paratype, with label (4) differing in the third line: "FREEMAN" and label (5) in the second line: " 253328 ". Condition of the type: pinned exemplar, without antennae.

Paratype male, with the same labels as in the fifth paratype, with label (4) differing in the third line: "FREEMAN" and label (5) in the second line: " 253327 ". Condition of the type: pinned exemplar, terminalia on slide.

Paratype male, with the same labels as in the fifth paratype, with label (4) differing in the third line: "FREEMAN" and label (5) in the second line: "253322". Condition of the type: pinned exemplar, without antennae.

Paratype male, with the same labels as in the fifth paratype, with label (4) differing in the third line: "FREEMAN" and label (5) in the second line: "253329". Condition of the type: pinned exemplar, without left antenna, terminalia in glycerin.

\section{Australosymmerus (Australosymmerus) basalis (Tonnoir, 1927) [Centrocnemis]}

Tonnoir, in Tonnoir \& Edwards, 1927: 759 (original description); plate 58, figure 1 (wing); plate 66, figures 129-130 (hypopygium). Type locality: [New Zealand, West Coast Region], Waiho River.

Paratype male, with labels: (1) printed on yellow round paper: "PARA- | TYPE"; (2) printed on white paper: "New Zealand: | West Coast, S.I. ii.1923. | T.R.Harris | B.M.1923-230.”; (3) printed with handwritten in- scriptions on white paper: "PARATYPE | Centrocnemis | basalis Tonnoir | det.J.E.Chainey,1995"; (4) printed on white paper: "BMNH(E) \# | 253299". Condition of the type: pinned exemplar, antenna and left wing broken distally, terminalia in glycerin.

Paratype male, with the same labels (1) and (3) as in the paratype above, with labels (2) printed on white paper: "New Zealand: | Raetihi Hill. | 3000ft. xi. 1923. | T.R.Harris | B.M.1924-22."; (4) printed on white paper: "BMNH(E) \# | 253300". Condition of the type: pinned exemplar, oxidized, left wing glued on rectangle plastic, terminalia in glycerin.

\section{Australosymmerus (Australosymmerus) nitidus (Tonnoir, 1927) [Centrocnemis]}

Tonnoir, in Tonnoir \& Edwards, 1927: 759 (original description); plate 58, figure 3 (wing); plate 66, figures 131-132 (hypopygium). Type locality: [New Zealand, Nelson], Dun Mountain.

Paratype male, with labels: (1) handwritten on white paper: "New Zealand: | Otira. | 10.I.1920. | G.W.Campbell. | 1923.125.”; (2) printed on yellow round paper: "PARA-|TYPE"; (3) printed on white paper: "BMNH(E) \# | 253295". Condition of the type: pinned exemplar, right wing glued on rectangle plastic, terminalia in glycerin.

\section{Australosymmerus (Australosymmerus) tillyardi (Tonnoir, 1927) [Centrocnemis]}

Tonnoir, in Tonnoir \& Edwards, 1927: 758 (original description); plate 58, figure 2 (wing); plate 66, figure 126 (hypopygium). Type locality: [New Zealand], Mount Arthur.

Paratype male, with labels: (1) handwritten on white paper: "New Zealand: | Otira. | 10.I.1920. | T.R.Harris."; (2) printed on white paper: "Pres. by | Dr. C.P.Alexander. | B.M.1922-91.”; (3) printed on yellow round paper: "PARA-|TYPE"; (4) printed with handwritten inscriptions on white paper: "PARATYPE | Centrocnemis | tillyardi | Tonnoir | det. J.E. Chainey,1995"; (5) printed on white paper: "BMNH(E) \# | 253294". Condition of the type: pinned exemplar, terminalia in glycerin.

Paratype male, with the same labels as in the paratype above, with label (5) differing in the second line: "253293". Condition of the type: pinned exemplar, left wing glued on rectangle plastic, without abdomen.

Paratype male, with labels: (1) handwritten on white paper: "362b"; (2) printed with handwritten inscriptions on white paper: "New Zealand: | Winlock, $\mid$ L.Wokotipu $\mid$ jan.1921. | G.V.Hudson"; with the same labels (3), (4) and (5) as in the first paratype, with label (5) differing in the second line: "253292". Condition of the type: pinned exemplar, abdomen in glycerin.

\section{Australosymmerus (Calosymmerus) bifasciatus (Williston, 1901) [Plesiastina]}

Williston, 1901: 217 (original description); tab. IV, figure 1 (habitus) and figure 1a (head, lateral view). Type locality: Mexico, Guerrero, Sierras de las Aguas Escondidas.

Lectotype male, designated by Munroe (1974:72), with labels: (1) printed on white paper: "Sierra de las | Aguas Escondidas, | Guerrero, 7000ft. | July.H.H.Smith.”; (2) printed on white paper: "B.C.A.Dipt. I. | Plesiastina | bifasciata, | Will."; (3) printed on white paper: "Central America. | Pres.by | F.D.Godman. | O.Savin. | 1903-172.”; (4) printed on dark blue round paper: "LECTO- | TYPE"; (5) printed on white paper: "Sp. figured."; (6) printed with handwritten inscriptions on red paper: "LECTOTYPE (DDM) $\mid$ Plesiastina $\mid$ bifasciata $\mid$ Williston"; (7) printed on white paper: "BMNH(E) \# | 253314". Condition of the type: pinned exemplar, without left antennae and legs, terminalia in glycerin.

Williston (1901) did not formally designate type specimens for Plesiastina bifasciata in his publication. He only indicated (1901: 217) that he examined three specimens from "Mexico, Sierra de la Aguas Escondidas in Guerrero, 7000' (H. H. Smith).” Munroe (1974) designed as lectotype a specimen bearing a "type" label (something not referred to in Williston's paper), and the other two specimens as paralectotypes. 
Paralectotype male, with labels: (1) printed on blue round paper: "Paralecto- | type"; (2) printed on white paper: "Sierra de las | Aguas Escondidas, | Guerrero, 7000ft.| July.H.H.Smith.”; (3) printed on white paper: "Central America. | Pres.by | F.D.Godman. | O.Savin. | 1903172.”; (4) printed on white paper: "B.C.A.Dipt. I. | Plesiastina| bifasciata, | Will.”; (5) printed on white paper: "Sp. figured.”; (6) printed with handwritten inscriptions on yellow paper: "LECTOPARATYPE | Plesiastina | Bifasciata | Williston"; (7) printed on white paper: "BMNH(E) \# | 253315". Condition of the type: pinned exemplar, without head, wings, and legs, terminalia in glycerin.

Paralectotype male, with labels: (1) printed on white paper: "Sierra de las Aguas Escondidas, | Guerrero, 7000ft. | July.H.H.Smith.”; (2) printed on white paper: "Sp. figured."; (3) printed on white paper: "B.C.A.Dipt. I. | Plesiastina | bifasciata, | Will."; (4) printed on white paper: "Central America. | Pres.by | F.D.Godman. | O.Savin. | 1903-172.”; (5) handwritten on white paper: "BMNH"; (6) printed on blue round paper: "Paralecto- | type"; (7) printed with handwritten inscriptions on yellow paper: "LECTOPARATYPE $\mid$ Plesiastina $\mid$ bifasciata $\mid$ Williston"; (8) printed on white paper: "BMNH(E) \# | 253316". Condition of the type: pinned exemplar, without antennae, wings and legs, terminalia in glycerin.

\section{Australosymmerus (Crionisca) aculeatus (Edwards,} 1921) [Centrocnemis]

Edwards, 1921: 434 (original description). Type locality: Australia, Tasmania, Mount Wellington.

Holotype female, with labels: (1) printed on red round paper: "Holo- | type"; (2) handwritten on white paper: "Centrocnemis | aculeata Edw."; (3) printed with handwritten inscriptions on white paper: "Tasmania: | Mt.Wellington | 7.X.1912 |A.White,|1917-104"; (4) printed with handwritten inscriptions on white paper: "HOLOTYPE | Centrocnemis | aculeata $\mid$ Edwards | det.J.E.Chainey,1995"; (5) printed on white paper: "BMNH(E) \# | 253289". Condition of the type: pinned exemplar, without antennae, right wing and legs.

\section{Australosymmerus (Crionisca) rieki (Colless, 1970) [Crionisca]}

Colless, 1970: 96 (original description); 97, figures 23-24 (female terminalia, lateral view) and figure 25 (gonocoxite). Type locality: Australia, Tasmania, Mount Wellington.

Paratype male, with labels: (1) printed on white paper: "Mt.Dom Dom, | Vic. | 22 Oct.1961 | D.H.Colless"; (2) printed on yellow round paper: "PARA| TYPE"; (3) printed with handwritten inscriptions on blue paper: "PARATYPE | Australosymmerus | rieki Colless"; (4) printed on white paper: "BMNH(E) \# | 253319". Condition of the type: pinned exemplar.

\section{Australosymmerus (Melosymmerus) bisetosus (Edwards, 1940) [Centrocnemis]}

Edwards, 1940: 442 (original description). Type locality: Brazil, Santa Catarina, [Seara], Nova Teutônia.

Lectotype male, presently designated, with labels: (1) printed on blue round paper: "SYN- | TYPE"; (2) printed on red round paper: "Type"; (3) printed with handwritten inscriptions on white paper: "1.9.1937| Brasilien | Nova Teutonia $27^{\circ} 11^{\prime} \mathrm{B}, 5^{\circ} 23^{\prime} \mathrm{L} \mid$ Fritz Plaumann”; (4) printed on white paper: "Brit. Mus. | 1938-40."; (5) printed with handwritten inscriptions on white paper: "Centrocnemis | bisetosa sp. nov. F.W.Edwards 1939"; (6) printed on white paper: "SYNTYPE| Centrocnemis | bisetosa Edwards | det.J.E.Chainey,1996"; (7) printed on white paper: "BMNH(E) \# | 253301; (8) printed on white paper: "LECTOTYPE | Australosymmerus (Melosymmerus) bisetosus | (Edwards, 1940) | Designated by Falaschi, RL \& Amorim, DS". Condition of the type: pinned exemplar.

In the original publication of this species, Edwards (1940) did not explicitly refer to a holotype. In the type-series, nevertheless, one of the syntypes has a "Type" label, as described above. This was noted by Munroe (1974:
67), who commented that such specimen should be chosen as the lectotype, but this is not to be considered a valid lectotype designation. This is followed for the formal lectotype designation made here.

Paralectotype (undetermined sex) with labels: (1) printed with handwritten inscriptions on white paper: "28.8.1938 | Brasilien | Nova Teutonia | $27^{\circ} 11^{\prime} \mathrm{B}, 52^{\circ} 23^{\prime} \mathrm{L}$ | Fritz Plaumann”; (2) printed on white paper: "Brit. Mus. 1938-682."; (3) printed on blue round paper: "SYN- | TYPE"; (4) printed on white paper: "SYNTYPE| Centrocnemis | bisetosa Edwards | det.J.E.Chainey,1996"; (5) printed on white paper: "BMNH(E) \# | 253302"; (6) printed on white paper: "PARALECTOTYPE Australosymmerus (Melosymmerus) bisetosus | (Edwards, 1940) | Designated by Falaschi, RL \& Amorim, DS". Condition of the type: pinned exemplar, without antennae and abdomen.

Paralectotype female with the same labels as in the second syntype, with labels (1) differing in the first line: "16.8.1937", (2) in the second line: "1937-656." and (5) in the second line: "253303". Condition of the type: pinned exemplar, without left wing.

Paralectotype male with the same labels as in the second syntype, with label (5) differing in the second line: "253307". Condition of the type: pinned exemplar.

Paralectotype female with the same labels (1), (2) and (6) as in the second syntype, with label (1) differing in the first line: "10.10.1938"; (3) printed on white paper: "Australosymmerus | bisetosus (Edw.) | det.D.D.MUNROE"; (4) printed on blue round paper: "SYN- | TYPE"; (5) printed on white paper: "SYNTYPE| Centrocnemis | bisetosa Edwards | det.J.E.Chainey, 1996"; (6) printed on white paper: "BMNH(E) \# | 253304". Condition of the type: pinned exemplar, without antennae, undetermined wing glued on triangle paper, without other wing.

Paralectotype male with the same labels as in the syntype above, with label (1) differing in the first line: "14.10.1938" and label (6) in the second line: "253305". Condition of the type: pinned exemplar, very damaged, without antennae, legs and left wing, abdomen with terminalia in glycerin.

Paralectotype male with the same labels (1), (2) and (6) as in the second syntype, with label (1) differing in the first line: "11.9.1937"; and label (2) in the second line: "1938-40."; with the same labels (3), (4) and (5) as in the fifth syntype; (6) printed on white paper: "NHM"; (7) printed on white paper: "BMNH(E) \# | 253306". Condition of the type: pinned exemplar, without antennae and left wing.

\section{Australosymmerus (Melosymmerus) pediferus (Edwards, 1940) [Centrocnemis]}

Edwards, 1940: 442 (original description). Type locality: Brazil, Santa Catarina, [Seara], Nova Teutônia.

Lectotype male, presently designated, with labels: (1) printed on blue round paper: "SYN-|TYPE"; (2) printed on red round paper: "Type"; (3) printed with handwritten inscriptions on white paper: "29.6.1938 | Brasilien | Nova Teutonia $\left|27^{\circ} 11^{\prime} \mathrm{B}, 52^{\circ} 23^{\prime} \mathrm{L}\right|$ Fritz Plaumann"; (4) printed with handwritten inscriptions on white paper: "Centrocnemis | pedifera Edw. F.W.Edwards 1939"; (5) printed on white paper: "SYNTYPE| Centrocnemis | pedifera Edwards | det.J.E.Chainey,1996"; (6) printed on white paper: "BMNH(E) \# | 253308"; (7) printed on white paper: "LECTOTYPE Australosymmerus (Melosymmerus) pediferus $\mid$ (Edwards, 1940) $\mid$ Designated by Falaschi, RL \& Amorim, DS". Condition of the type: pinned exemplar, without left antenna, left wing glued on rectangle paper.

In the case of this species as well, Edwards (1940) did not designate a type specimen in the original publication, so the label in the specimen referred to above does not denote a holotype. This was also as noted by Munroe (1974: 67), who had a personal communication from Anthony M. Hutson. Munroe (1974) suggested that this specimen should be designated as lectotype, what is formally made here.

Paralectotype female with labels: (1) printed with handwritten inscriptions on white paper: “30.8.1937| Brasilien | Nova Teutonia $\mid 27^{\circ} 11^{\prime} \mathrm{B}, 52^{\circ} 23^{\prime} \mathrm{L}$ | Fritz Plaumann"; (2) printed on white paper: "Brit. Mus. | 1938-40.”; (3) printed with handwritten inscriptions on white paper: "Australosymmerus |pediferus (Edw.) | det. D.D.MUNROE"; (4) printed on blue round paper: "SYN-|TYPE"; (5) printed on white paper: "SYNTYPE | Centrocnemis 
| pedifera Edwards | det.J.E.Chainey,1996"; (6) printed on white paper: "BMNH(E)\#|253311"; (7) printed on white paper: "PARALECTOTYPE | Australosymmerus (Melosymmerus) pediferus | (Edwards, 1940)|Designated by Falaschi, RL \& Amorim, DS". Condition of the type: pinned exemplar, left antenna distally broken.

Paralectotype female with the same labels as in the syntype above, with label (6) differing in the second line: "253313". Condition of the type: pinned exemplar, both wings glued on rectangle paper.

Paralectotype male with the same labels (1), (2), (6) and (7) as in the second syntype, with label (1) differing in the first line: "26.7.1938"; label (2) in the second line: "1938-682." and (6) in the second line: "253310"; (3) printed on blue round paper: "SYN- | TYPE"; (4) printed on white paper: "SYNTYPE | Centrocnemis | pedifera Edwards | det. J.E. Chainey,1996"; (5) printed on white paper: "NHM". Condition of the type: pinned exemplar, abdomen glued on triangle paper, wings on a slide, without left antenna.

Paralectotype female with the same labels (1), (2) and (7) as in the second syntype, with label (1) differing in the first line: "11.5.1938" and label (2) in the second line: "1938-458."; with the same labels (3) and (4) as in the syntype above; (5) printed on white paper: "BMNH(E) \#|253312". Condition of the type: pinned exemplar.

Paralectotype female with the same labels as in the second syntype, with label (1) differing in the first line: "16.8.1937", label (2) in the second line: "1938-682." and (6) in the second line: "253309". Condition of the type: pinned exemplar, left antenna distally broken, without legs, undetermined wing and abdomen glued on rectangle paper.

\section{Australosymmerus (Melosymmerus) truncatus Munroe, 1974}

Munroe, 1974: 69 (original description); 157, figure 39 (male terminalia); 173, figure $65 \mathrm{f}$ (wing); 178, figure 73 (phylogeny). Type locality: Mexico, Sinaloa.

Paratype male, with labels: (1) printed with handwritten inscriptions on yellow round paper: "Para- | type |B.M.1972-341"; (2) handwritten on white paper: "15 mi W. El Palmito. Sin. | Mex.5000' Malaise | Trap 4.VIII.1964"; (3) printed with handwritten inscriptions on blue paper: "PARATYPE $\mid$ Australosymmerus $\mid$ truncatus $\mid$ Munroe"; (4) printed on white paper: "BMNH(E) \# | 253354". Condition of the type: pinned exemplar, without left antenna.

\section{Australosymmerus (Tantrus) montorum Munroe, 1974}

Munroe, 1974: 62 (original description); 151, figure 33 (male terminalia); 172, figure 641 (wing); 178, figure 72 (phylogeny). Type locality: Ecuador, Azuay, Cerro Tinajillas.

Paratype male, with labels: (1) printed on yellow paper: "Para- | type"; (2) printed on white paper: "Cerro Tinajillas | Azuay, ECUADOR | 1821.III.1965 |3100m., L.Pena"; (3) printed with handwritten inscriptions on blue paper: "PARATYPE $\mid$ Australosymmerus $\mid$ montorum $\mid$ Munroe"; (4) handwritten on white paper: "Brit.Mus. | 1972-341"; (5) printed on white paper: "BMNH(E) \# $\mid 253355$ ". Condition of the type: pinned exemplar, without right wing and abdomen, terminalia in glycerin.

\section{Australosymmerus (Vellicocauda) insolitus (Walker, 1837) [Platyura]}

Walker, 1837: 335 (original description). Type locality: Chile [Puerto del Hambre, Straits of Magellan].

Holotype male, with labels: (1) printed with handwritten inscriptions on blue round paper: "Platyura $\mid$ Type $\mid$ insolita $\mid$ Walk."; (2) printed on red round paper: "HOLO- | TYPE."; (3) handwritten on blue round paper: "63 | 43"; (4) handwritten on white paper: "Chil"; (5) handwritten on white paper: "Platyura ? | insolita Walk"; (6) handwritten on white paper: "S.America | Capt.King."; (7) printed on white paper: "HOLOTYPE O" of | Platyura insolita | Walker, 1837 | Det. N.P.Wyatt $2002 \mid$ PORT FAMINE, Straits | of Magellan, P.P.King"; (8) printed on white paper:
"BMNH(E) \# | 253352". Condition of the type: pinned exemplar, without wings, abdomen glued on rectangle plastic, terminalia in balsam.

\section{Australosymmerus (Vellicocauda) maculatus Munroe, 1974}

Munroe, 1974: 61 (original description); 150, figure 32 (male terminalia); 172 , figure $64 \mathrm{k}$ (wing); 178, figure 72 (phylogeny). Type locality: Chile, Aysén, Mañiguale River.

Paratype male, with labels: (1) printed on yellow round paper: "Para- | type"; (2) handwritten on white paper: "CHILE:Rio | Chaguigua 460m | 18.III.1965 | L.E.Pena"; (3) printed with handwritten inscriptions on blue paper: "PARATYPE $\mid$ Australosymmerus $\mid$ maculates Munroe"; (4) handwritten on white paper: "Brit.Mus.| 1972-341"; (5) printed on white paper: "BMNH(E) \# | 253356". Condition of the type: pinned exemplar, terminalia in glycerin.

\section{Australosymmerus (Ventrilobus) cornutus Colless, 1970}

Colless, 1970: 95 (original description); 87, plate I, figure F (wing); 93, figure 17 (male terminalia, lateral view) and figure 18 (male terminalia, ventral view). Type locality: Australia, New South Wales, Clyde Mountain.

Paratype male, with labels: (1) printed on white paper: "Rutheford Ck. | Brown Mtn.,N.S.W. | 19.Jan.1961 | D.H.Colless"; (2) printed on yellow round paper: "Para- | type"; (3) printed with handwritten inscriptions on blue paper: "PARATYPE | Australosymmerus | cornutus Colless"; (4) printed on white paper: "BMNH(E) \# | 253320". Condition of the type: pinned exemplar.

\section{Australosymmerus (Ventrilobus) fuscinervis (Edwards, 1921) [Centrocnemis]}

Edwards, 1921: 433 (original description). Type locality: Australia, Tasmania, Mangalore.

Lectotype male, designated by Colless (1970: 88), with labels: (1) printed on blue round paper: "SYN- | TYPE."; (2) printed on red round paper: "Type"; (3) printed with handwritten inscriptions on white paper: "Tasmania: | Mangalore.| 14.IX.1914. A. White.|1917-104"; (4) handwritten on white paper: "Centrocnemis | fuscinervis Edw."; (5) printed with handwritten inscriptions on white paper: "SYNTYPE | Centrocnemis |fuscinervis | Edwards | det.J.E.Chainey, 1995"; (6) printed with white paper: "BMNH(E)\#|253290". Condition of the type: pinned exemplar, without abdomen.

Paralectotype male with labels: (1) printed on blue round paper: "SYN- | TYPE."; (2) printed with handwritten inscriptions on white paper: "Tasmania: | Mangalore. | 4.X.1913. | A. White. | 1917-104”; (3) printed with handwritten inscriptions on white paper: "SYNTYPE Centrocnemis $\mid$ fuscinervis $\mid$ Edwards $\mid$ det.J.E.Chainey, 1995”; (4) printed with white paper: "BMNH(E) \# | 253291". Condition of the type: pinned exemplar, without abdomen.

Colless (1970: 88) designated one of Edwards' syntypes of this species as lectotype, noting: "[a holotype was not formally] designated by the author, but a specimen in BM (Mangalore, 14.ix.1914, A. White) bears a holotype label. I hereby designate it as a lectotype. Another specimen (same data, 4.x.1913) is a paralectotype. Both have abdomens missing, but, from their size, are almost certainly males." This means that the specimen is formally a lectotype, but probably Colless did not either see the specimen or add a lectotype label to the specimen. A lectotype label will be sent to the NHM to be added to the specimen.

\section{Australosymmerus (Ventrilobus) nebulosus Colless, 1970}

Colless, 1970: 92 (original description); 87, plate I, figure D (wing); 93 , figure 11 (male terminalia, ventral view), figure 12 (male terminalia, lateral view) and figure 13 (gonocoxite). Type locality: Australia, Tasmania, Heyler Gorge. 
Paratype male, with labels: (1) printed on white paper: "Bogong, Vic. |24.1.65 | N.Dobrotworsky"; (2) printed on yellow round paper: "PARA-|TYPE."; (3) printed with handwritten inscriptions on blue paper: "PARATYPE | Australosymmerus | nebulosus Colless"; (4) printed with white paper: "BMNH(E) \#| 253318". Condition of the type: pinned exemplar.

\section{Nervijuncta bicolor Edwards, 1927}

Edwards, in Tonnoir \& Edwards, 1927: 770 (original description); plate 59 , figure 20 (wing); plate 68, figure 151 (hypopygium) and figure 152 (clasper). Type locality: New Zealand, Ohakune.

Holotype male, with labels: (1) printed red round paper: "Type"; (2) handwritten on white paper: "Nervijuncta | bicolor Edw."; (3) printed on red round paper: "HOLO- | TYPE"; (4) printed with handwritten inscriptions on white paper: "New Zealand: | Ohakune. | IV.iii.1923. | T.R.Harris | B.M.1923-263.”; (5) printed with handwritten inscriptions on white paper: "HOLOTYPE $\mid$ Nervijuncta $\mid$ bicolor $\mid$ Edwards $\mid$ det. J.E. Chainey,1995"; (6) printed on white paper: "BMNH(E) \# | 253400". Condition of the type: pinned exemplar, terminalia in balsam.

Paratype male, with labels: (1) printed yellow round paper: "PARA- |TYPE"; (2) printed on white paper: "New Zealand: | Ohakune. | x.xi.1922. | T.R.Harris | B.M.1923-13."; (3) printed with handwritten inscriptions on white paper: "PARATYPE | Nervijuncta | bicolor | Edwards | det.J.E.Chainey,1995"; (4) printed on white paper: "BMNH(E) \# | 253401". Condition of the type: pinned exemplar.

Paratype male, with the same labels as in the first paratype, with label (2) differing in the third line: "15.xii.22-15.i.23." and fifth: "B.M.1923126.", and label (4) differing in the second line: "253403". Condition of the type: pinned exemplar, oxidized.

Paratype male, with the same labels as in the first paratype, with label (2) differing in the third line: "Jan.1924." and fifth: "B.M.1924-99.", and label (4) differing in the second line: "253404". Condition of the type: pinned exemplar, without antennae, oxidized.

Paratype male, with the same labels as in the paratype above, with label (4) differing in the second line: " 253405 ". Condition of the type: pinned exemplar, without antennae, oxidized.

Paratype female, with the same labels as in the paratype above, with label (4) differing in the second line: "253407". Condition of the type: pinned exemplar, without antennae, oxidized.

Paratype (undetermined sex) with the same labels (1) and (2) as in the third paratype; (3) handwritten on white paper: "N. bicolor"; (4) printed on white paper: "PARATYPE $\mid$ Nervijuncta $\mid$ bicolor $\mid$ Edwards | det.J.E.Chainey,1995"; (5) printed on white paper: "BMNH(E) \# | 253406 ". Condition of the type: pinned exemplar, very damaged, without abdomen, right wing glued in rectangle plastic, oxidized.

\section{Nervijuncta conjuncta (Freeman, 1951) [Ditomyia]}

Freeman, 1951: 7 (original description); plate I, figure 1 (male terminalia); plate XLVI, figure 297 (wing). Type locality: Argentina, Rio Negro, Correntoso Lake.

Holotype male, with labels: (1) printed with handwritten inscriptions on red round paper: "Ditomyia $\mid$ Type | conjuncta"; (2) printed on white paper: "L.Correntoso. | 18-25.xi.1926."; (3) printed on red round paper: "HOLO- | TYPE"; (4) printed on white paper: "Argentina: | Terr.Rio Negro. | F. \& M.Edwards. | B.M.1927-63"; (5) printed on white paper: "BMNH(E) \# | 253280". Condition of the type: pinned exemplar, without antennae, legs and right wing, terminalia in balsam.

Paratype male, with labels: (1) printed on white paper: "Casa Pangue. | 410.xii.1926."; (2) printed with handwritten inscriptions on yellow paper: "Ditomyia $\mid$ conjuncta $\mid$ Freeman | PARATYPE."; (3) printed on white paper: "S.Chile: | Llanquihue prov. | F. \& M. Edwards. | B.M.1927-63."; (4) printed on white paper: "BMNH(E) \# | 253281". Condition of the type: pinned exemplar, without antennae.

Paratype male, with labels: (1) printed on white paper: "Ancud. | 1719.xii.1926."; (2) printed on yellow round paper: "PARA- | TYPE"; (3) printed with handwritten inscriptions on yellow paper: "Ditomyia conjuncta $\mid$ Freeman | PARATYPE.”; (4) printed on white paper: "S.Chile: | Chiloe I. | F. \& M. Edwards. | B.M.1927-63"; (5) printed on white paper: "BMNH(E) \# | 253282". Condition of the type: pinned exemplar, terminalia in glycerin.

Paratype male, with the same labels (2), (3) and (5) as in the paratype above, with label (5) differing in the second line: "253283"; (1) printed on white paper: "L. Gutierrez. |3-14.xi.1926."; (4) printed on white paper: "Argentina: | Terr.Rio Negro. | F. \& M. Edwards. | B.M.1927-63.”. Condition of the type: pinned exemplar, without antennae, legs broken, left wing glued on rectangle paper.

\section{Nervijuncta harrisi Edwards, 1927}

Edwards, in Tonnoir \& Edwards, 1927: 766 (original description); plate 67, figure 146 (hypopygium) and 171, figure 147 (clasper). Type locality: New Zealand, Ohakune.

Holotype male, with labels: (1) printed on red round paper: "Type"; (2) handwritten on white paper: "Nervijuncta | harrisi Edw."; (3) printed on red round paper: "HOLO- |TYPE"; (4) printed on white paper: "New Zealand: | Ohakune. | ii.1924. | T.R.Harris | B.M.1924-278.”; (5) printed with handwritten inscriptions on white paper: "PARATYPE | Nervijuncta | harrisi | Edwards | det.J.E.Chainey,1995"; (6) printed on white paper: "BMNH(E) \# | 253370". Condition of the type: pinned exemplar, terminalia in balsam.

Paratype male, with labels: (1) printed on yellow round paper: "PARATYPE"; (2) printed on white paper: "New Zealand: | Ohakune. | xi.1923. | T.R.Harris | B.M.1924-22."; (3) printed with handwritten inscriptions on white paper: "PARATYPE | Nervijuncta $\mid$ harrisi $\mid$ Edwards det.J.E.Chainey,1995"; (4) printed on white paper: "BMNH(E) \# | 253371". Condition of the type: pinned exemplar.

\section{Nervijuncta hexachaeta Edwards, 1927}

Edwards, in Tonnoir \& Edwards, 1927: 766 (original description); plate 59, figure 18 (wing); plate 67, figure 146 (hypopygium). Type locality: New Zealand, Ohakune.

Holotype male, with labels: (1) printed on red round paper: "Type"; (2) handwritten on white paper: "Nervijuncta | hexachaeta Edw."; (3) printed on red round paper: "HOLO- |TYPE"; (4) printed on white paper: "New Zealand: | Ohakune. | 15.xii.22-15.i.23. | T.R.Harris | B.M.1923-126.”; (5) printed with handwritten inscriptions on white paper: "HOLOTYPE $\mid$ Nervijuncta $\mid$ hexachaeta $\mid$ Edwards | det.J.E.Chainey,1995”; (6) printed on white paper: "BMNH(E) \# | 253363". Condition of the type: pinned exemplar, terminalia in balsam.

Paratype male, with labels: (1) handwritten on white paper: "354e"; (2) printed on yellow round paper: "PARA-|TYPE"; (3) printed with handwritten inscriptions on white paper: "New Zealand: | Wiltons Bush, | Wellington $\mid$ XI.1921 | G.V.Hudson, | B.M.1922-236.”; (4) printed with handwritten inscriptions on white paper: "PARATYPE $\mid$ Nervijuncta $\mid$ hexachaeta $\mid$ Edwards | det.J.E.Chainey,1995"; (5) printed on white paper: "BMNH(E) \# | 253364". Condition of the type: pinned exemplar.

Paratype female, with the same labels (4) and (5) as in the first paratype, with label (5) differing in the second line: "2533654"; (1) printed on yellow round paper: "PARA- |TYPE"; (2) printed on white paper: "Otira N.Z. 7 Feb. 1922 | A.Tonnoir"; (3) printed on white paper: "New Zealand: | A.Tonnoir | B.M.1922-348.”. Condition of the type: pinned exemplar, without antennae.

Paratype female, with labels: (1) printed on yellow round paper: "PARATYPE"; (2) handwritten on white paper: "New Zealand: | Glenorchy 4.I.1923 |C.C.Fenwick | 1923.150.”; (3) printed with handwritten inscriptions on white paper: "PARATYPE $\mid$ Nervijuncta $\mid$ hexachaeta $\mid$ Edwards | det.J.E.Chainey,1995"; (4) printed on white paper: "BMNH(E)\#|253366". Condition of the type: pinned exemplar, without legs and abdomen.

Paratype male, with the same labels (1), (3) and (4) as in the third paratype, with label (4) differing in the second line: "253368"; (2) handwritten on white paper: "New Zealand: | Weraroa | 7.IX.1911 | D.Miller.". Condition of the type: pinned exemplar. 
Paratype male, with the same labels (1), (3) and (4) as in the third paratype, with label (4) differing in the second line: "253367"; (2) printed on white paper: "New Zealand: | West Coast, S.I. | ii.1923. | T.R.Harris | B.M.1923-230". Condition of the type: pinned exemplar, oxidized.

\section{Nervijuncta longicauda Edwards, 1927}

Edwards, in Tonnoir \& Edwards, 1927: 765 (original description); plate 58 , figure 16 (wing); plate 67, figure 139 (hypopygium). Type locality: New Zealand, Wellington, Otari-Wilton's Bush.

Holotype male, with labels: (1) handwritten on white paper: "354a"; (2) printed on red round paper: "Type"; (3) handwritten on white paper: "Nervijuncta | longicauda Edw"; (4) printed on red round paper: "HOLO- TYPE"; (5) printed with handwritten inscriptions on white paper: "New Zealand: | Wiltons Bush, | Wellington |XI.1921 | G.V.Hudson, | B.M.1922-236.”; (6) printed with handwritten inscriptions on white paper: "PARATYPE $\mid$ Nervijuncta $\mid$ longicauda $\mid$ Edwards | det.J.E.Chainey,1995"; (7) printed on white paper: "BMNH(E) \# | 253369 ". Condition of the type: pinned exemplar, terminalia in balsam.

\section{Nervijuncta marshalli Edwards, 1927}

Edwards, in Tonnoir \& Edwards, 1927: 769 (original description); plate 58 , figure 6 (wing). Type locality: New Zealand, Ohakune.

Holotype male, with labels: (1) printed on red round paper: "HOLO- |TYPE"; (2) handwritten on white paper: "Nervijuncta | marshalli Edw."; (3) printed on white paper: "New Zealand: | Ohakune. | iii.1923. | T.R.Harris | B.M.1923-263."; (4) printed with handwritten inscriptions on white paper: "HOLOTYPE | Nervijuncta $\mid$ marshalli $\mid$ Edwards | det. J.E. Chainey,1995"; (5) printed on white paper: "BMNH(E) \# | 253397". Condition of the type: pinned exemplar, left wing glued on rectangle plastic.

\section{Nervijuncta nigricornis Tonnoir, 1927}

Tonnoir, in Tonnoir \& Edwards, 1927: 767 (original description); plate 58, figure 9 (wing). Type locality: [New Zealand, Wellington], Days Bay.

Paratype male, with labels: (1) printed on yellow round paper: "PARATYPE"; (2) printed on white paper: "New Zealand: | Ohakune. | 15.xii.22-15.i.23. | T.R.Harris | B.M.1923-126.”; (3) printed with handwritten inscriptions on white paper: "PARATYPE | Nervijuncta | nigricornis | Edwards | det.J.E.Chainey,1995"; (4) printed on white paper: "BMNH(E) \# $\mid 253393$ ". Condition of the type: pinned exemplar.

Paratype male, with the same labels as in the paratype above, with label (2) differing in the third line: "xi.23." and fifth: "B.M.1924-22.", and label (4) differing in the second line: "253394". Condition of the type: pinned exemplar, right wing glued on rectangle plastic paper.

\section{Nervijuncta nigricoxa Edwards, 1927}

Edwards, in Tonnoir \& Edwards, 1927: 770 (original description); plate 68, figure 149 (hypopygium) and figure 150 (clasper). Type locality: New Zealand, Ohakune.

Holotype male, with labels: (1) printed on red round paper: "Type"; (2) handwritten on white paper: "Nervijuncta $\mid$ nigricoxa Edw."; (3) printed on red round paper: "Holo- | type"; (4) printed on white paper: "New Zealand: | Ohakune.|15.xii.22-15.i.23. | T.R.Harris | B.M.1923-126.”; (5) printed with handwritten inscriptions on white paper: "PARATYPE $\mid$ Nervijuncta nigricoxa $\mid$ Edwards | det.J.E.Chainey,1995"; (6) printed on white paper: "BMNH(E) \# | 253399". Condition of the type: pinned exemplar, left wing and abdomen glued on rectangle plastic paper, terminalia in balsam.

\section{Nervijuncta ostensackeni Tonnoir, 1927}

Tonnoir, in Tonnoir \& Edwards, 1927: 767 (original description); plate 58, figure 4 (wing); plate 66, figure 133 (clasper). Type locality: [New Zealand, West Coast Region, Westland District], Otira.

Paratype male, with labels: (1) printed on yellow round paper: "PARATYPE"; (2) printed on white paper: "New Zealand: | Ohakune. Jan.1924. | T.R.Harris | B.M.1924-99.”; (3) printed on white paper:
"PARATYPE $\mid$ Nervijuncta ostensackeni $\mid$ Tonnoir det. J.E. Chainey,1995"; (4) printed on white paper: "BMNH(E) \# | 253384". Condition of the type: pinned exemplar, without antennae, oxidized.

Paratype male, with the same labels as in the first paratype, with label (4) differing in the second line: "253388". Condition of the type: pinned exemplar, without antennae, oxidized.

Paratype male, with the same labels as in the first paratype, with label (4) differing in the second line: "253389". Condition of the type: pinned exemplar, without antennae, oxidized.

Paratype male, with the same labels as in the first paratype, with label (4) differing in the second line: "253390". Condition of the type: pinned exemplar, without antennae, oxidized.

Paratype male, with the same labels as in the first paratype, with label (4) differing in the second line: "253391". Condition of the type: pinned exemplar, without antennae, oxidized.

Paratype male, with the same labels as in the first paratype, with label (4) differing in the second line: "253392". Condition of the type: pinned exemplar, without antennae, oxidized.

Paratype male, with the same labels as in the first paratype, with label (4) differing in the second line: "253386". Condition of the type: pinned exemplar, without antennae and abdomen, oxidized.

Paratype male, with the same labels as in the first paratype, with label (4) differing in the second line: "253387". Condition of the type: pinned exemplar, without left wing, oxidized.

Paratype male, with the same labels as in the first paratype, with label (4) differing in the second line: "253378". Condition of the type: pinned exemplar, oxidized.

Paratype male, with the same labels as in the first paratype, with label (2) differing in the third line: "15.xii.22-15.i.23" and fifth: "B.M.1923126.", and label (4) differing in the second line: "253380". Condition of the type: pinned exemplar.

Paratype male, with the same labels as in the first paratype, with label (2) differing in the third line: "xi.1922." and fifth: "B.M.1923-13.", and label (4) differing in the second line: "253377". Condition of the type: pinned exemplar, right antenna glued on rectangle plastic, oxidized.

Paratype male, with the same labels as in the paratype above, with label (4) differing in the second line: "253376". Condition of the type: pinned exemplar.

Paratype male, with the same labels as in the first paratype, with label (2) differing in the third line: "v-vii.1923." and fifth: "B.M.1923-419.", and label (4) differing in the second line: "253383". Condition of the type: pinned exemplar, oxidized.

Paratype male, with the same labels as in the first paratype, with label (2) differing in the third line: "v-vii.1923." and fifth: "B.M.1923-419.", and label (4) differing in the second line: "253381". Condition of the type: pinned exemplar, oxidized.

Paratype male, with the same labels as in the first paratype, with label (2) differing in the third line: "v-vii.1923." and fifth: "v-vii.1923." and fifth: "B.M.1923-419.", and label (4) differing in the second line: "253382". Condition of the type: pinned exemplar, without antennae, oxidized.

Paratype male, with the same labels as in the first paratype, with label (2) differing in the third line: "v-vii.1923." and fifth: "B.M.1923-419.", and label (4) differing in the second line: " 253385 ". Condition of the type: pinned exemplar, left wing glued on rectangle plastic, oxidized.

Paratype male, with the same labels as in the first paratype, with label (2) differing in the third line: "v-vii.1923." and fifth: "B.M.1923-419.", and label (4) differing in the second line: "253383". Condition of the type: pinned exemplar, oxidized.

Paratype female, with the same labels as in the first paratype, with label (2) differing in the third line: "ii.1923." and fifth: "B.M.1923-230.", and label (4) differing in the second line: "253379". Condition of the type: pinned exemplar, oxidized.

\section{Nervijuncta parvicauda Edwards, 1927}

Edwards, in Tonnoir \& Edwards, 1927: 763 (original description); plate 68, figure 153 (hypopygium). Type locality: New Zealand, Ohakune. 
Holotype male, with labels: (1) printed on red round paper: "Holo- | type"; (2) printed on red round paper: "Type"; (3) handwritten on white paper: "Nervijuncta | parvicauda Edw."; (4) printed on white paper: "New Zealand: | Ohakune. | Jan.1924. | T.R.Harris | B.M.1924-99.”; (5) printed with handwritten inscriptions on white paper: "PARATYPE $\mid$ Nervijuncta | parvicauda | Edwards | det.J.E.Chainey,1995"; (6) printed on white paper: "BMNH(E) \# | 2533659". Condition of the type: pinned exemplar, terminalia in balsam, oxidized.

Paratype male, with labels: (1) printed on yellow round paper: "PARATYPE"; (2) printed on white paper: "New Zealand: | Ohakune. | Jan.1924. | T.R.Harris | B.M.1924-99.”; (3) printed with handwritten inscriptions on white paper: "PARATYPE $\mid$ Nervijuncta $\mid$ parvicauda $\mid$ Edwards | det.J.E.Chainey,1995"; (4) printed on white paper: "BMNH(E) \# $253360 "$ ". Condition of the type: pinned exemplar.

Paratype male, with the same labels as in the first paratype, with label (4) differing in the second line: "253361". Condition of the type: pinned exemplar, without antennae, terminalia in balsam.

Paratype female, with labels: (1) printed on red round paper: "Holo- | type"; (2) printed on red round paper: "Type"; (3) handwritten on white paper: "Nervijuncta | parvicauda | var. suffusa Edw."; (4) printed on white paper: "New Zealand: | Ohakune. | Jan.1924. | T.R.Harris | B.M.1924-99."; (5) printed with handwritten inscriptions on white paper: "PARATYPE Nervijuncta $\mid$ parvicauda $\mid$ var. suffusa $\mid$ Edwards $\mid$ det. J.E. Chainey,1995"; (6) printed on white paper: "BMNH(E) \# | 253362". Condition of the type: pinned exemplar, left wing and abdomen glued on rectangle plastic.

\section{Nervijuncta pilicornis Edwards, 1927}

Edwards, in Tonnoir \& Edwards, 1927: 764 (original description). Type locality: New Zealand, Ohakune.

Holotype female, with labels: (1) printed on red round paper: "HOLO- | TYPE"; (2) printed on red round paper: "Type"; (3) handwritten on white paper: "Nervijuncta | pilicornis Edw."; (4) printed on white paper: "New Zealand: | Ohakune. | 15.xii.22-15.i.23. | T.R.Harris | B.M.1923-126."; (5) printed with handwritten inscriptions on white paper: "PARATYPE Nervijuncta $\mid$ pilicornis $\mid$ Edwards | det. J.E. Chainey,1995"; (6) printed on white paper: "BMNH(E) \# | 253368". Condition of the type: pinned exemplar, left wing glued on rectangle plastic.

\section{Nervijuncta pulchella Edwards, 1927}

Edwards, in Tonnoir \& Edwards, 1927: 768 (original description); plate 58, figure 17 (wing). Type locality: New Zealand, Ohakune.

Paratype female, with labels: (1) printed on red round paper: "HOLO- | TYPE"; (2) printed on red round paper: "Type"; (3) handwritten on white paper: "Nervijuncta | pulchella Edw."; (4) printed on white paper: "New Zealand: | Ohakune. | ii.1923. | T.R.Harris | B.M.1923-230."; (5) printed with handwritten inscriptions on white paper: "PARATYPE $\mid$ Nervijuncta $\mid$ pulchella $\mid$ Edwards | det.J.E.Chainey,1995”; (6) printed on white paper: "BMNH(E)\#| 253398". Condition of the type: pinned exemplar, left wing and abdomen glued on rectangle plastic.

\section{Nervijuncta ruficeps Edwards, 1927}

Edwards, in Tonnoir \& Edwards, 1927: 762 (original description); plate 58, figure 10 (wing); plate 67, figure 137 (hypopygium) and figure 138 (clasper). Type locality: New Zealand, Ohakune.

Holotype male, with labels: (1) printed on red round paper: "Type"; (2) handwritten on white paper: "Nervijuncta | ruficeps Edw."; (3) printed on red round paper: "HOLO-|TYPE"; (4) printed on white paper: "New Zealand: | Ohakune. | xi.1923. |T.R.Harris | B.M.1924-22.”; (5) printed with handwritten inscriptions on white paper: "PARATYPE $\mid$ Nervijuncta $\mid$ ruficeps | Edwards | det.J.E.Chainey,1995"; (6) printed on white paper: "BMNH(E) $\# \mid$ 253372". Condition of the type: pinned exemplar, left wing and abdomen glued on rectangle plastic, terminalia in balsam.

Paratype male, with labels: (1) printed on yellow round paper: "PARA- | TYPE"; (2) printed on white paper: "New Zealand: | Ohakune. 15.xii.22-15.i.23. | T.R.Harris | B.M.1923-126."; (3) printed with hand- written inscriptions on white paper: "PARATYPE $\mid$ Nervijuncta $\mid$ ruficeps | Edwards | det.J.E.Chainey,1995"; (4) printed on white paper: "BMNH(E) \# | 253373". Condition of the type: pinned.

Paratype male, with the same labels as in the first paratype, with label (4) differing in the second line: "253374". Condition of the type: pinned.

Paratype male, with labels: (1) printed on red round paper: "HOLO- |TYPE"; (2) printed on red round paper: "Type."; (3) handwritten on white paper: "Nervijuncta | ruficeps | var. continua Edw."; (4) handwritten on white paper: "New Zealand: | Karaka Grove, | Sinclair Head. 14.XI.1923. | C.V.Hudson. | B.M.1924-287."; (5) printed with handwritten inscriptions on white paper: "HOLOTYPE | Nervijuncta ruficeps var. |continua $\mid$ Edwards | det.J.E.Chainey,1995";(6) printed on white paper: "BMNH(E) \# | 253375". Condition of the type: pinned.

\section{Nervijuncta wakefield Edwards, 1927}

Edwards, in Tonnoir \& Edwards, 1927: 762 (original description). Type locality: New Zealand, Queenstown.

Holotype female, with labels: (1) printed on red round paper: "HOLOTYPE"; (2) handwritten on white paper: "Nervijuncta | wakefield | var. abbreviata |Edw."; (3) printed on white paper: "New Zealand: Queenstown | 4.XI.1924. | L.Curtis. | B.M.1925-141.”; (4) printed with handwritten inscriptions on white paper: "HOLOTYPE $\mid$ Nervijuncta $\mid$ wakefield var. | abbreviata Tonnoir \& | Edwards | det.J.E.Chainey,1995"; (5) printed on white paper: "BMNH(E) \# | 253357". Condition of the type: pinned exemplar.

\section{Rhipidita fusca Edwards, 1940}

Edwards, 1940: 442 (original description); plate 18, figure 1 (wing). Type locality: Brazil, Santa Catarina, [Seara], Nova Teutônia.

Holotype male, with labels: (1) printed on red round paper: "Holo- | type"; (2) printed on white paper: "Type"; (3) printed with handwritten inscriptions on white paper: "Rhipidita |fusca Edw. | F.W.Edwards 1932"; (4) printed with handwritten inscriptions on white paper: "ix.1932 Brasilien | Nova Teutonia | $27^{\circ} 11^{\prime} \mathrm{B}, 52^{\circ} 23^{\prime} \mathrm{L}$ | Fritz Plaumann"; (5) printed on white paper: "Brit. Mus. |1939-66"; (6) printed on white paper: "NHM."; (7) printed with handwritten inscriptions on white paper: "HOLOTYPE $\mid$ Rhipidita $\mid$ fusca $\mid$ Edwards $\mid$ det.J.E.Chainey,1996"; (8) printed on white paper: "BMNH(E) \# | 253284". Condition of the type: pinned exemplar, without left wing, terminalia on slide.

\section{Symmerus (Symmerus) antennalis Okada, 1936}

Okada, 1936: 58 (original description); 58, figure 1a (antenna), figure $1 \mathrm{~b}$ (wing) and figure 1c (male terminalia). Type locality: Japan, Hokkaido. Paratype male, with labels: (1) printed on yellow round paper: "PARATYPE"; (2) printed with handwritten inscriptions on white paper: "Sapporo | I. Okada Back: MARUYAMA | 25/VI-1935"; (3) handwritten on white paper: "Brit. Mus. | 1937-194"; (4) printed with handwritten inscriptions on white paper: "Symmerus $\mid$ antennalis $\mid$ Okada $\mid$ det. I. Okada"; (5) printed on white paper: "BMNH(E) \# | 253285". Condition of the type: pinned exemplar, left wing distally broken, terminalia on glycerin.

\section{Symmerus (Psilosymmerus) fuscicaudatus Saigusa, 1973}

Saigusa, 1973: 189 (original description); 183, figure 14 (head, lateral view) and figure 15 (head, frontal view); 186, figure 29 (female terminalia, lateral view) and figure 30 (female terminalia, ventral view); 191, figure 36 (male terminalia, lateral view), figure 37 (male terminalia, ventral view), figure 38 (male terminalia, posteroventral view), figure 39 (left cercus, dorsal view), figure 40 (phallus, dorsal view), figure 41 (phallus, lateral view); plate 9 , figure 8 (habitus); plate 10, figure 9 (habitus). Type locality: Japan, Honshu, Akaishi Mountains, Kitazawa-tôge, Mt. Senjô-dake. Paratype male, with labels: (1) printed on yellow round paper: "PARATYPE"; (2) handwritten on white paper: "Kisikomagatake | Kiso Mts. HONSHU | 9.VIII.1963 | T.SAIGUSA"; (3) printed on white paper: "pres. T.Saigusa | BM.1980-443"; (4) handwritten on white paper with 
red borders: "[PARATYPE] | Symmerus | fuscicaudatus | SAIGUSA 1972"; (5) printed on white paper: "BMNH(E) \# | 253286". Condition of the type: pinned exemplar.

\section{Symmerus (Psilosymmerus) vockerothi Munroe, 1974}

Munroe, 1974: 29 (original description); 125, figure 7 (male terminalia); 171, figure 63f (wing); 176, figure 69 (phylogeny). Type locality: Canada, Quebec, Old Chelsea.

Paratype male, with labels: (1) printed on yellow round paper: "Para- | type"; (2) printed with handwritten inscriptions on white paper: "King Mtn., Old | Chelsea, Que. | 1000' 12.VII.69 | Malaise Trap"; (3) printed on white paper: "D.D.Munroe | Collector"; (4) handwritten on white paper: "Brit. Mus. | 1972-341."; (5) printed on white paper: "BMNH(E) \# 253287". Condition of the type: pinned exemplar.

Paratype male, with the same labels as in the paratype above, with label (5) differing in the second line: " 253288 ". Condition of the type: pinned exemplar.

\section{ACKNOWLEDGEMENTS}

The authors are indebted with Erica McAlister (NHM, London, England) for the kind reception at NHM and the access to the collection. We thank Dr. Nelson Papavero (MZUSP, São Paulo, SP, Brazil) and Sarah Oliveira (Universidade de São Paulo, Brazil) for useful comments on an earlier draft of the manuscript and Dr. Silvio Nihei (Universidade de São Paulo, Brazil) and the two anonymous referees for valuable comments on the manuscript. During the preparation of this paper, the first author had financial support from FAPESP with a PhD Fellowship Grant 2007/59466-8, while the second author has CNPq Research Grant 314371/2009-5.

\section{REFERENCES}

Amorim, D.S. \& Rindal, E. 2007. Phylogeny of the Mycetophiliformia, with proposal of the subfamilies Heterotrichinae, Ohakuneinae, and Chiletrichinae for the Rangomaramidae (Diptera, Bibionomorpha). Zootaxa 1535: 1-92.

Bechev, D. \& Chandler, P. 2011. Catalogue of the Bolitophilidae and Diadocidiidae of the World (Insecta: Diptera). Zootaxa 2741: 38-58.

Blagoderov, V. \& Grimaldi, D. 2004. Fossil Sciaroidea (Diptera) in Cretaceous ambers, exclusive of Cecidomyiidae, Sciaridae, and Keroplatidae. American Museum Novitates 3433: 1-76.

Blagoderov, V. 2007. Fungus Gnats Online. Available from: http:// www.sciaroidea.info/node/23335 (accessed 26 June 2012).

Colless, D.H. 1970. The mycetophilidae (Diptera) of Australia Part 1. Introduction, key to subfamilies, and review of Ditomyiinae. Journal Australian Entomological Society 9: 83-99.

Edwards, F.W. 1921. A note on the dipterous subfamily Ditomyinae, with descriptions of new recent and fossil forms. Annals and Magazine of Natural History 7: 431-437.

Edwards, F.W. 1925. British fungus-gnats (Diptera, Mycetophilidae). With a revised generic classification of the family. Transactions of the Royal Entomological Society of London 1924: 505-670

Edwards, F.W. 1940. New Neotropical Mycetophilidae (IV) (Diptera). Revista de Entomologia 11: 440-465.

Edwards, F.W. 1941. Notes on British fungus- gnats (Dipt., Mycetophilidae). Entomologist's Monthly Magazine 77: 21-82.

Evenhuis, N.L. 1994. Catalogue of the Fossil Flies of the World (Insecta: Diptera). Leiden, Backhuys, 600 p.

Freeman, P. 1951. Diptera of Patagonia and South Chile based mainly on material in the British Museum (Natural History). III Mycetophilidae. London, British Museum (Natural History), 138 p.
Hennig, W. 1954. Flügelgeäder und System der Dipteren unter Berücksichtigung der aus dem Mesozoicum beschriebenenFossilien. Beiträge zur Entomologie 4: 245-388.

Hippa, H. \& Vilkamaa, P. 2005. The genus Sciarotricha gen. n. (Sciaridae) and the phylogeny of recent and fossil Sciaroidea (Diptera). Insect Systematics \& Evolution 36: 121-144.

ICZN (International Commission of Zoological Nomenclature). 1999. International Code of Zoological Nomenclature. Fourth edition, adopted by the International Union of Biological Sciences. International Trust for Zoological Nomenclature. London, The Natural History Museum, xxx+306 p.

Landrock, K. 1912. Zur Monographie der Gattung Bolitophila Meig. Berliner Entomologische Zeitschrift 57: 33-51.

Mamaev, B.M. \& Krivosheina, M.P. 1988. Ditomyiidae, p. 197-198. In: Soós, A. \& Paap, L. (eds.). Catalogue of Palaearctic Diptera. Volume 3. Ceratopogonidae - Mycetophilidae. Budapest, Akadémiai Kiadó, 448 p + 1 map.

Munroe, D.D. 1974. The systematics, phylogeny, and zoogeography of Symmerus Walker and Australosymmerus Freeman (Diptera: Mycetophilidae: Ditomyiidae). Memoirs of the Entomological Society of Canada 92: 1-183.

Okada, I. 1936. Beitrag zur Kenntnis der Fungivoriden-Fauna Japans III: Ditomyiinae (Dipt.). Insecta Matsumurana 9: 56-60.

Plassmann, E. 1988. Bolitophilidae, p. 193-196. In: Soós, A. \& Paap, L. (eds.). Catalogue of Palaearctic Diptera. Volume 3. Ceratopogonidae - Mycetophilidae. Budapest, Akadémiai Kiadó, 448 p + 1 map.

Ribeiro, G.C., Lamas, C.J.E. \& Azevedo, L.N.S. 2007. A catalogue of the types of Limoniidae and Tipulidae (Diptera: Tipulomorpha) in the collection of the Museu de Zoologia da Universidade de São Paulo, Brazil. Zootaxa 1497: 1-22.

Rindal, E., Søli, G. \& Gammelmo, Ø. 2008. On the family Bolitophilidae (Diptera, Mycetophiliformia) in Norway. Norwegian Journal of Entomology 55: 169-173.

Saigusa, T. 1973. A Systematic study of the Mycetophilidae of Japan (Diptera) Part. 1 A Revision of the subfamily Ditomyiinae. Sieboldia 4: 167-215.

Sasakawa, M. 2004. Diadocidiidae and Borboropsidae (Insecta: Diptera) of Japan, with descriptions of two new species. Species Diversity 9: 207-214.

Ševčík, J. 2003. Three new species of Diadocidiidae (Diptera) from Papua New Guinea. Entomological Problems 33: 63-68.

Ševčík, J. \& Papp, L. 2004. Bolitophilidae (Diptera) from Taiwan: a family new to the Oriental region. Acta Zoologica Academiae Scientiarum Hungaricae 50: 55-62.

Stackelberg, A.A. 1969. 30. Order Diptera, p. 5-55. In: Bei-Bienko, G.Ya. (ed.). [Keys to the Insects of the European USSR.]. Nauka, Leningrad [in Russian].

Tonnoir, A.L. \& Edwards, F.W. 1927. New Zealand fungus gnats (Diptera, Mycetophilidae). Transactions of the New Zealand Institute 57: 747878 .

Walker, F. 1836. Notes on Diptera. Entomological Magazine 4: 113-117.

Walker, F. 1837. Descriptions, etc., of the insects collected by Captain P.P. King, R.N., F.R.S., in the survey of the Straits of Magellan. Transactions of the Linnean Society of London 17: 331-359.

Williston, S.W. 1901. Diptera. In: Godman, F.D. \& Salvin, O. (eds.). Biologia Centrali-Americana. Zoologia-Insecta-Diptera. Vol. 1, London, $378 \mathrm{p}$.

Yamaguchi, C. \& Lamas, C.J.E. 2009. A catalogue of the types of Asiloidea (Diptera) in the collection of the Museu de Zoologia da Universidade de São Paulo, Brazil (Part 1: Bombyliidae and Mydidae). Zootaxa 2146: $35-42$.

Received 21 June 2012; accepted 18 March 2013

Associate Editor: Silvio S. Nihei 